\title{
The Impact of Stock Index Futures on the Information Environment of Listed Firm: Evidence from Chinese Listed Firms
}

\author{
Yinglin Wan ${ }^{1}$ \\ ${ }^{1} \mathrm{PhD}$ of Accountancy College, Central University of Finance and Economics, China, PRC \\ Correspondence: Yinglin Wan, Accountancy College, Central University of Finance and Economics, China. \\ E-mail: lynnwan@outlook.com
}

Received: February 14, 2018

Accepted: March 14, 2018

Online Published: April 18, 2018

doi:10.5539/ijbm.v13n5p147

URL: https://doi.org/10.5539/ijbm.v13n5p147

\begin{abstract}
We investigate the impact of stock index futures on the information environment of listed firms through the launch of Shanghai-Shenzhen 300 stock index futures (CSI 300 index) as natural experiment on April 16, 2010. We employ difference in difference analysis and apply the PIN indicator (the probability of informed trading) to measure information asymmetry. We found that the CSI 300 index significantly reduce the information asymmetry of CSI 300 companies. For the companies with higher market capitalization, higher turnover rate and higher institutional investor's rate, the impact of stock index future on the corporate information environment is more significant. The results of this paper provide new evidence for evaluating the impacts of Chinese stock index futures.
\end{abstract}

Keywords: stock index futures, information environment, information asymmetric

\section{Introduction}

Morton Miller, winner of the Nobel Prize in economics, believes that the relationship between financial derivatives such as stock index futures and the spot market is "two doors of one house." Through the replication of spot transactions, stock index futures provide investors with a more convenient access to the world of risk. China launched CSI300 stock index futures on April 16, 2010, initiating the short selling mechanism in China's securities market. The introduction of stock index futures is of great significance to the institutional construction of Chinese capital market. First, the price variation of stock index futures is earlier than the price variation in the stock index. Through the short mechanism, investors' expectations on bad news can be reflected in the variations in futures prices, which affects the changes in stock indexes. Second, the transaction costs of the stock index futures market is lower and the response of stock index future market to new information is faster than the spot market. All of these promote the information disclosure, and more reasonable market price.

The influential mechanism of stock index futures on the spot market is also through information environment, which is a multiplayer game. Futures and spot market participants have more mining capabilities and requirements for more disclosure, which enlarge the market and increase the number of informed investors. Grossman (1977) found that the futures market will pass more information from informed investors to uninformed investors. The introduction of futures markets will increase the amount of information reflected in stock prices (Powers, 1970; Green, 1986; Froot \& Perold, 1995; Fleming, Kirby, \& Ostdieki, 1998; Ates \& Wang, 2005). Stock index futures can motivate investors to collect the information of listed company, reduce the degree of information asymmetry, and then improve the company's information environment. However, some researchers think that the futures market does not provide new information to the stock market (Covey and Bessler, 1995).

Chinese stock market has encountered stock crash on 2015, the stock price of spot market fall all the way down from the highest point. In addition to the scrutiny of "malicious short-selling" and "high-frequency trading", the public even suggest to close the stock index future. On September 2th, China International Capital Corporation (CICC) limits the trade volume and raises the deposit requirement. After one year, the turnover rate of CSI300 Index futures is $0.5 \%$ of the turnover rate on June 2015, and the turnover rate of the SSE 50 Index Futures and the CSI 500 Index Futures was only $0.7 \%$ and $2.6 \%$ on June 2015 . No evidence has shown that stock index futures are the reason of stock crash. The effect of introducing stock index futures in our country is still uncertain. Does stock index future improve the information environment of listed companies? The answer to this question 
has significant theoretical and practical value.

In this paper, we use the launch of CSI 300 stock index futures as natural experiment and construct difference in difference framework (DID) to analysis the influence of stock index future on the information asymmetry of listed companies and information environment. We find that the launch of CSI 300 stock index futures significantly reduces the information asymmetry of CSI 300 stocks. Moreover, for the companies with higher market capitalization, higher turnover and higher institutional investor's ratio, the impact on the corporate information environment is more significant.

The contributions of our research are listed below. First, we enrich the literature on the influence of stock index futures on corporate information environment. Most of the existing literature are focus on the value discovery function and volatility spillover effect of stock index futures, and simply interprets the influence of information environment as the information transmission effect (Zhao, 2008; Miao \& Feng, 2008). However from the perspective of the company's information environment, the conduction mechanism on the influence of information environment to the spot market is still unclarified.

Second, the article provides new evidence for the influential factors of information environment of listed companies. Most of the previous literatures focus on whether the introduction of the futures market could improve the information reflection speed of the spot market shorten the impact of information on the spot market and improve the information communication efficiency in the spot market (Powers, 1970; Grossman, 1977; Damodaran, 1990; Shi \& Qiu, 2007). We investigate on how these factors affect the information environment under different conditions.

Third, our study has practical value to the policy making of government. Good information environment is an important foundation for achieving the synergies between the futures market and the spot market. Stock index futures could enhance the breadth, content and depth of the spot market (Mckenzie, 2001). We should learn from other countries and regions in developing stock index futures and constantly strengthen the coordinated management of information sharing between the futures market and the spot market for risk management and control. Through development of stock index futures, we could reduce market volatility, stabilize the market and promote market development.

Many literatures have study the impact of futures market on the information environment of the spot market. Evidences were provided that the futures market can help to alleviate the information asymmetry in the spot market. For example, Bessembinder and Seguin $(1992,1993)$ show that derivatives markets do enhance trades, improve information asymmetry in futures markets and price discovery. All of these could slow down spot market volatility, increase market depth, and promote information assimilation efficiency in spot market. Stroll and Whaley (1988) and Powers (1970) also pointed out that stock index futures improve the information content of financial market, including the information depth, communication speed and breadth, and promote the efficiency of information exchange and price discovery. Cox (1976) studies six commodity futures by constructing a special effective market model and finds that futures trading can increase the efficiency of resource allocation in the spot market and speed up the information transfer in the spot market, so as to provide more complete and accurate buyers and sellers Price information. Merton (1995) argues that the trading of futures and other derivatives can reduce the information asymmetry between market participants and improve the efficiency of market information. Antoniou and Holmes (1995) used the GARCH model and daily return data to study the impact of the FTSE100 index futures on the spot market volatility. The result shows that the futures transaction leads to the increase of volatility in the spot market. However, the volatility does not originate from the negative effects of speculators disrupting, but from the increase of information. The introduction of the futures market improves the speed and quality of information in the spot market. Therefore, the existence of the stock index futures market enriches the form of information exchange, expands the scope and content of information exchange, and improves the efficiency of information dissemination. The increase of information, the enhance of information speed and quality may increase market turbulence.

However, studies have shown that the introduction of stock index futures has no effect on the information asymmetry of spot market, and the introduction of stock index futures may increases the information asymmetry in the spot market. For example, Antoniou and Holmes (1995) find that after the listing of futures, the volatility of the spot stock price is significantly affected by the new information while the impact of the old information significantly decreases. After changing to a floating exchange rate, the unconditional variance of the daily return rate increased significantly, while the conditional variance became less sensitive and predictable to the new information in the previous disturbance item. All of these are indicating today's information becomes less important in predicting tomorrow's volatility. Finglewski (1981) also concludes that futures traders have less 
information resources than stock traders, which increases the information asymmetry in the stock market. Stein (1987) further suggests that the futures market can attract more investors with low information because of the high leverage in the futures market. The trading behavior of such a large number of investors will reduce the information contained in the stock price, thus increasing the information asymmetry of stock spot market.

For this reason, we propose the following hypotheses:

H1a: The introduction of stock index futures will reduce the degree of information asymmetry of the listed companies.

H2a: The introduction of stock index futures will increase the degree of information asymmetry of the listed companies.

In addition, the companies with higher market value and higher turnover ratio are prone to affected by the information environment of spot market. However, as the stock index futures market can provide more information on value discovery, companies with higher turnover rates will have more individual investors shifted from the stock market to the stock index futures market, so the impact of stock index futures on listed companies with higher turnover ratio is more significant. For this reason, we propose the following hypotheses:

H3: For companies with higher market value, the introduction of stock index futures has a more significant impact on the information asymmetry of the listed companies.

H4: For companies with higher turnover ratio, the introduction of stock index futures has a more significant impact on the information asymmetry.

For companies with a higher ratio of institutional ownership and more analysts, the profitability as well as the market value of shares is higher than other listed companies. Thus these companies are prone to be influenced by market environment. For this reason, we propose the following hypotheses:

H5: The introduction of stock index futures has a more significant impact on the information asymmetry of the listed companies with higher institutional ownership.

H6: The introduction of stock index futures has a more significant impact on the information asymmetry of the listed companies with more analysts.

\section{Method}

\subsection{Data and Sample Selection}

The sample period is before and after one year of stock index futures (250 trading days), the pre-event window period is from April 9th, 2009 to April 15th, 2010 and the post-event window is from April 16th, 2010 to April 28th, 2011. The treatment group is the CSI 300 Index; the control group is CSI 500 Index. Excluding the stocks adjusted by the treatment group during the sample period and the stocks listed less than one month, we have 196 stocks in the treatment group and 277 stocks in control group. The financial data are from the WIND financial database and Tinysoft financial analysis platform.

\subsection{Model and Variables}

To control the influence of systemic factors such as the CSI 300 stock index futures, we mainly adopts the DID model, which is widely used in recent years to evaluate the policy effect. The model has been gradually applied in various fields of economy and finance. Imbens and Wooldridge (2007) point out, in natural experiments, the treatment group (the group affected by the policy) and the control group (the group that are not affected by the policy) come from specific group affected by specific policy. Therefore DID model can better control systematic difference between treatment and control groups and study the changes of the treatment groups before and after the policy implementation. We constructs the following DID model to study how stock index futures affects the information asymmetry of stock:

\subsubsection{Dependent Variable}

$$
\begin{gathered}
\text { PIN }_{\mathrm{i}, t}=C+\beta_{1} \text { TREAT }+\beta_{2} P O S T+\beta_{3} \text { TREAT*POST }+ \text { Ah }+ \text { State_own }+\ln m v \\
+P b+\text { To }+ \text { Org }+ \text { Analyst }+\sum \operatorname{Industries~}+\varepsilon_{i}
\end{gathered}
$$

The dependent variable PIN is the probability distribution of informed investors. In this paper, we use percentage of informed trade (PIN) to measure information asymmetry to measure the information environment of listed companies. PIN is measured by the imbalance of purchase orders and sale orders in the given time to estimate the level of informed trading. According to Easley, Kiefer, O'Hara, and Paperman (1996), the best measurement of information asymmetry in empirical studies is the PIN indicator. Probability distribution of informed investors can be estimated based on the SAS procedure of Xiaoyun Yu in Indiana University. 


\subsubsection{Independent Variable}

The experimental variables include TREAT and POST. POST is a dummy variable for identifying stock index futures. The value of POST is 1 after the stock index futures launch; otherwise, the value is 0 . TREAT is a dummy variable that identifies CSI 300 Index. The value of TREAT is 1 for CSI 300 Index; the value of TREAT is 0 for CSI 500 Index.

\subsubsection{Control Variable}

The control variable include State、Size、PB、Turnover、Org、Analyst. State is for state-owned enterprise. Size is the natural logarithm of the market value of the company. PB is the ratio of the market capitalization of the company. Turnover is the turnover ratio of the company. Org is the institutional investor's shareholding. Analyst is the number of financial analysts of the company. Table 1 is the definition and measurement of all variables.

Table 1. variable definition and measurement

\begin{tabular}{ll}
\hline Variable & Definition \\
\hline Independent variable & \\
TREAT & The value of TREAT is 1 for CSI 300 Index; \\
& The value of TREAT is 0 for CSI 500 Index. \\
The value of POST is 1 after the stock index futures launch; & Otherwise, the value is 0 \\
POST & The probability distribution of informed investors \\
Dependent variable & \\
PIN & If the company contains H stock, Ah $=1$. Otherwise, Ah $=0$ \\
Control variable & If the company is state-owned, State $=1$. Otherwise, State $=0$ \\
Ah & If the company is private-owned, Private $=1$. Otherwise, Private $=1$ \\
State & The natural logarithm of the market value of company \\
Private & The price to book ratio of company \\
Size & The price to earning ration of company \\
$P b$ & The turnover ratio of circulation stock \\
$P e$ & The ratio of institutional shareholder of company \\
To & The following analyst of company \\
Org &
\end{tabular}

\subsection{Descriptiave Analysis}

Table 2 shows the descriptive statistics of variables. There was no obvious ex ante trend in PIN in the treatment group and the control group, which shows that our empirical design meets the requirements of difference in difference model. In addition, the trend of market value, the price to book ratio, turnover ratio and institutional ownership ratio are similar, which means the change is market-wide. Table 3 shows the t-test and Wilcoxon test for the PIN index of the treatment group and control group. The result of the two tests shows that the experiment group and control group have significant differences.

Table 2. Descriptive analysis

\begin{tabular}{|c|c|c|c|c|c|c|c|c|c|c|c|c|c|}
\hline \multirow{2}{*}{ VARIABLE } & \multirow{2}{*}{ Group } & \multicolumn{2}{|c|}{ Skewness } & \multicolumn{2}{|c|}{ Kurtosis } & \multicolumn{2}{|l|}{ Std } & \multicolumn{2}{|l|}{ Min } & \multicolumn{2}{|c|}{ Mean } & \multicolumn{2}{|l|}{$\operatorname{Max}$} \\
\hline & & Pre & Post & Pre & Post & Pre & Post & Pre & Post & Pre & Post & Pre & Post \\
\hline \multirow{2}{*}{ PIN } & $\mathrm{T}$ & 0.82 & 0.33 & 3.11 & 4.99 & 0.02 & 0.02 & 0.03 & 0.01 & 0.08 & 0.08 & 0.16 & 0.18 \\
\hline & $\mathrm{C}$ & 0.92 & 0.37 & 4.37 & 3.29 & 0.02 & 0.02 & 0.04 & 0.04 & 0.10 & 0.11 & 0.20 & 0.20 \\
\hline
\end{tabular}


Table 3. T test and Wilcoxon test of treatment group and control group

\begin{tabular}{llc}
\hline & $\begin{array}{l}\mathrm{t}=0 \text { vs } \mathrm{t}=1 \\
\text { T statistics }\end{array}$ & Z statistics \\
\hline Pin & 0.00 & $-3.548^{* * *}$ \\
State & 0.00 & 0.00 \\
Inmv & 0.30 & 0.53 \\
$P b$ & -0.15 & -0.12 \\
$P e$ & 0.07 & -0.33 \\
To & 0.68 & -0.32 \\
Org & 0.06 & 0.06 \\
Analyst & 0.60 & 0.68 \\
\hline
\end{tabular}

\section{Results}

We first examine the changes in information asymmetry between the treatment and control groups over the period. Compared with stock index futures market, the stock index futures market significantly improve the information exchange efficiency of the stock market, promote the stock value discovery and the information exposure. In addition, after the launch of stock index futures, investors who do not have private information have the motivation to move from the stock market to the stock index futures market. For professional investors with private information, especially institutional investors, they will remain in the stock market and arbitrage through private information. In this section we mainly based on difference in difference model to estimate the impact of information asymmetry on stock index futures. There is no obvious ex ante trend in the information asymmetry between the treatment group and the control group, which shows that our empirical design meets the requirements of the difference in difference model. The results of Model 2 are similar to Model 1, the index futures trading significantly reduces the degree of information asymmetry in the treatment group.

Table 4. Regression result of stock index future and percentage of informed trade

\begin{tabular}{lll}
\hline \multirow{2}{*}{ VARIABLES } & Basic & Control \\
\cline { 2 - 3 } TREAT & $\mathbf{( 1 )}$ & $\mathbf{( 2 )}$ \\
\cline { 2 - 3 } POST & -0.014 & -0.006 \\
& $(-5.30)^{* * *}$ & $(-1.62)$ \\
TREAT*POST & 0.016 & 0.012 \\
& $(8.08)^{* * *}$ & $(5.38)^{* * *}$ \\
State & -0.015 & -0.012 \\
& $(-5.33)^{* * *}$ & $(-4.01)^{* * *}$ \\
MV & & 0.000 \\
& & $(0.00)$ \\
Pb & & -0.014 \\
& & $(-6.53)^{* * *}$ \\
Turnover & & 0.001 \\
& & $(1.98)^{* *}$ \\
Org & & -0.702 \\
& & $(-8.26)^{* * *}$ \\
Industry Dummies & & 0.000 \\
Constant & Included & $(2.49)^{* *}$ \\
Observations & 0.101 & Included \\
\hline R-squared & $(59.25)^{* * *}$ & 0.305 \\
Robust t-statistics in parentheses & & $(9.28)^{* * *}$ \\
\hline & 0.172 & 832 \\
\hline
\end{tabular}




\begin{tabular}{|c|c|c|c|c|}
\hline \multirow[t]{2}{*}{ VARIABLES } & $\begin{array}{l}\text { Lower } \\
\text { MV }\end{array}$ & $\begin{array}{l}\text { Higher } \\
\text { MV }\end{array}$ & $\begin{array}{l}\text { Lower } \\
\text { turnover }\end{array}$ & $\begin{array}{l}\text { Higher } \\
\text { turnover }\end{array}$ \\
\hline & (3) & (4) & (5) & (6) \\
\hline \multirow[t]{2}{*}{ TREAT } & 0.003 & -0.002 & 0.005 & 0.016 \\
\hline & $(0.30)$ & $(-0.45)$ & $(1.10)$ & $(5.84)^{* * *}$ \\
\hline \multirow[t]{2}{*}{ POST } & 0.018 & 0.014 & -0.018 & 0.001 \\
\hline & $(6.56)^{* * *}$ & $(2.69)^{* * *}$ & $(-3.13)^{* * *}$ & $(0.15)$ \\
\hline \multirow[t]{2}{*}{ TREAT*POST } & -0.027 & -0.016 & -0.003 & -0.023 \\
\hline & $(-2.84)^{* * *}$ & $(-2.82)^{* * *}$ & $(-0.53)$ & $(-4.40) * * *$ \\
\hline \multirow[t]{2}{*}{ State } & -0.002 & 0.003 & 0.001 & 0.001 \\
\hline & $(-0.88)$ & $(1.00)$ & $(0.31)$ & $(0.22)$ \\
\hline \multirow[t]{2}{*}{$\operatorname{lnmv}$} & -0.022 & -0.011 & -0.006 & -0.015 \\
\hline & $(-5.24)^{* * *}$ & $(-5.20)^{* * *}$ & $(-1.98)^{* *}$ & $(-2.96)^{* * *}$ \\
\hline \multirow[t]{2}{*}{$\mathrm{Pb}$} & 0.002 & 0.001 & 0.002 & 0.001 \\
\hline & $(2.75)^{* * *}$ & $(1.60)$ & $(2.81)^{* * *}$ & $(0.64)$ \\
\hline \multirow[t]{2}{*}{ Turnover } & -0.524 & -1.132 & 0.000 & -0.000 \\
\hline & $(-5.32)^{* * *}$ & $(-8.47)^{* * *}$ & $(0.09)$ & $(-1.29)$ \\
\hline \multirow[t]{2}{*}{ IO } & 0.001 & 0.000 & -1.423 & -0.576 \\
\hline & $(2.79)^{* * *}$ & $(0.91)$ & $(-3.07)^{* * *}$ & $(-3.06)^{* * *}$ \\
\hline \multirow[t]{2}{*}{ Analyst } & 0.038 & 0.017 & 0.001 & 0.000 \\
\hline & $(4.59)^{* * *}$ & $(2.78)^{* * *}$ & $(2.88)^{* * *}$ & $(1.25)$ \\
\hline \multirow[t]{2}{*}{ Constant } & 0.415 & 0.278 & 0.298 & 0.508 \\
\hline & $(6.40)^{* * *}$ & $(7.68)^{* * *}$ & $(8.14)^{* * *}$ & $(9.46)^{* * *}$ \\
\hline Industry dummies & Included & Included & Included & Included \\
\hline Observations & 416 & 416 & 416 & 416 \\
\hline R-squared & 0.283 & 0.319 & 0.413 & 0.313 \\
\hline
\end{tabular}

Robust t-statistics in parentheses

\begin{tabular}{|c|c|c|c|c|c|}
\hline \multirow[t]{2}{*}{ VARIABLES } & \multirow{2}{*}{$\begin{array}{l}\text { Lower } \\
\text { institution } \\
(7) \\
\end{array}$} & \multicolumn{2}{|l|}{$\begin{array}{l}\text { Higher } \\
\text { institution }\end{array}$} & \multirow[t]{2}{*}{$\begin{array}{l}\text { Less } \\
\text { analyst }\end{array}$} & \multirow{2}{*}{$\begin{array}{l}\text { More } \\
\text { Analyst } \\
(10) \\
\end{array}$} \\
\hline & & (8) & $(9)$ & & \\
\hline \multirow[t]{2}{*}{ TREAT } & 0.013 & 0.012 & & 0.013 & 0.012 \\
\hline & $(3.64)^{* * *}$ & $(3.89)^{* * *}$ & & $(4.65)^{* * *}$ & $(2.65)^{* * *}$ \\
\hline \multirow[t]{2}{*}{ POST } & -0.020 & -0.011 & & -0.004 & -0.017 \\
\hline & $(-3.16)^{* * *}$ & $(-2.20)^{* *}$ & & $(-0.66)$ & $(-2.96)^{* * *}$ \\
\hline \multirow[t]{2}{*}{ TREAT*POST } & -0.007 & -0.014 & & -0.008 & -0.013 \\
\hline & $(-1.42)$ & $(-3.72)^{* * *}$ & & $(-1.70)^{*}$ & $(-2.48)^{* *}$ \\
\hline \multirow[t]{2}{*}{ State } & 0.001 & 0.002 & & -0.000 & 0.003 \\
\hline & $(0.20)$ & $(0.70)$ & & $(-0.02)$ & $(0.69)$ \\
\hline \multirow[t]{2}{*}{$\operatorname{lnmv}$} & -0.005 & -0.007 & & -0.017 & -0.002 \\
\hline & $(-1.76)^{*}$ & $(-2.36)^{* *}$ & & $(-4.35)^{* * *}$ & $(-0.99)$ \\
\hline \multirow[t]{2}{*}{$\mathrm{Pb}$} & 0.002 & 0.001 & & 0.001 & 0.000 \\
\hline & $(1.72)^{*}$ & $(1.34)$ & & $(2.35)^{* *}$ & $(0.50)$ \\
\hline \multirow[t]{2}{*}{ Turnover } & 0.000 & -0.000 & & 0.000 & -0.000 \\
\hline & $(0.25)$ & $(-0.10)$ & & $(0.07)$ & $(-0.12)$ \\
\hline \multirow[t]{2}{*}{ IO } & -0.860 & -0.827 & & -0.938 & -0.726 \\
\hline & $(-4.17)^{* * *}$ & $(-4.01)^{* * *}$ & & $(-6.83)^{* * *}$ & $(-2.93)^{* * *}$ \\
\hline \multirow[t]{2}{*}{ Analyst } & -0.001 & 0.001 & & -0.000 & 0.001 \\
\hline & $(-1.68)^{*}$ & $(3.81)^{* * *}$ & & $(-0.08)$ & $(3.93)^{* * *}$ \\
\hline \multirow[t]{2}{*}{ Constant } & 0.259 & 0.333 & & 0.431 & 0.243 \\
\hline & $(5.30)^{* * *}$ & $(7.63)^{* * *}$ & & $(7.74)^{* * *}$ & $(6.57)^{* * *}$ \\
\hline Industry dummies & Included & Included & & Included & Included \\
\hline Observations & 416 & 416 & & 416 & 416 \\
\hline R-squared & 0.297 & 0.385 & & 0.306 & 0.394 \\
\hline
\end{tabular}


The empirical results are shown in Table 4. We find that for listed companies in the CSI 300 Index or the CSI 500 Index, the PIN (percentage of informed trade ratio) has dropped significantly since the launch of stock index futures, reducing the market information asymmetry. More importantly, we found a significant incremental change in the PIN value of both CSI 500 Index and CSI 300 Index, which is significant at the $1 \%$ level. The above results show that the launch of stock index futures helps to reduce the market information asymmetry. In TABLE 4 Column (1), the coefficient of POST is negative, significant at $1 \%$ level. The coefficient of TREAT*POST represents the incremental effect of stock index future to the information asymmetry of CSI 300 Index is very significant $(\beta 3=-0.012, \mathrm{t}=-5.43)$.

The result shows that the launch of stock index futures significantly improves the information asymmetry of market. Among the control variables, the PIN index is significantly related to the company's market value, price to book ratio and turnover ratio. In TABLE5, we use sub group regression divided by market value, turnover ratio, institutional ownership ratio, the number of analysts, and the nature of ownership of the firm.

We further examine how the differences in firm characteristics affect the relevance of stock index futures and corporate information environment. We first divide the sample into two groups by size (the company's market value) for sub-group regression. In Table 5, we could see that the introduction of stock index futures has a greater impact on the stocks of high market value than stocks of low market value. The stocks of high market value (usually larger companies), many of which are healthy and well-managed companies, are prone to be chosen by investors as targets. We also divide the sample into two groups according to the turnover rate. Compared to companies with lower turnover ratio, the result shows that the impact of stock index futures on the listed companies with higher turnover ratio is more significant. Many companies with lower turnover rates are over-hyped, while the stock index futures market can weaken its negative impact.

Then we divide the sample into two groups by the institutional investors' ratio, and the results show that the impact of stock index futures are more significant for listed companies with higher institutional ownership. Listed companies with a higher proportion of institutional investors are stable to pressure and less risk-averse. Last we divided the sample into two groups by the number of follow analysts, the results show that for the listed companies with more follow analysts, the launch of stock index futures market has more significant effect on the information asymmetry.

To test the robustness of the empirical results, we also try to add margin trading as control variables in the model. We find that the main empirical results remain robust. In addition, due to the relatively small stock index futures market in China and short building-up period, we use the sample data from Japanese and U.S. stock index futures markets to conduct regression analysis. The empirical results support our conclusion. The impact of stock index futures on stock information asymmetry is very significant. Compared to listed companies with lower market value, the impact of index stock market on the information asymmetry of listed companies with higher market value is more significant. The stock index futures have a greater impact on the information asymmetry of companies with higher turnover rates. In addition, the involvement of institutional investors can significantly reduce information asymmetry. Thus, the empirical results of this paper are robust.

\section{Discussion}

This article is written from the perspective of information environment to study the impact of stock index futures on the spot market. We find that the introduction of CSI 300 Index futures could significantly reduce the information asymmetry of CSI 300 stocks. Compared with the listed companies with lower market value, the CSI 300 Index futures have a greater impact on the listed companies with higher market value, and significantly decrease the degree of information asymmetry of listed companies; For the listed companies with higher market to book ratio and turnover rate, stock index futures market can significantly influence its information asymmetry, and improve its information environment. In this paper, we use the launch of CSI 300 stock index futures as natural experiment and construct difference in difference framework (DID) to analysis the influence of stock index future on the information asymmetry of listed companies and information environment. We find that the launch of CSI 300 stock index futures significantly reduces the information asymmetry of CSI 300 stocks. Moreover, for the companies with higher market capitalization, higher turnover and higher institutional investor's ratio, the impact on the corporate information environment is more significant.

We enrich the literature on the influence of stock index futures on corporate information environment and provides new evidence for the influential factors of information environment of listed companies. Our study has practical value to the policy making of government. Good information environment is an important foundation for achieving the synergies between the futures market and the spot market.We should learn from other countries and regions in developing stock index futures and constantly strengthen the coordinated management of 
information sharing between the futures market and the spot market for risk management and control. Through development of stock index futures, we could reduce market volatility, stabilize the market and promote market development.By promoting the development of high-capitalization companies, increasing turnover and the proportion of institutional investors, we could create better protection for investors and information environment. Through better information disclosure, we could improve the information environment and optimizing the structure of the securities market. Our research shows that the introduction of stock index futures have significant effect in improving the market information environment and protecting the right of investors.

\section{Acknowledgements}

The author thank Central University of Finance and Economics, China for Graduate Innovation Research Grants No.201508

\section{References}

Allen, F., \& Gale, D. (1991). Arbitrage, short sales, and financial innovation. Econometrica, 59(4), 1041-1068. https://doi.org/10.2307/2938173

Ashenfelter, O., \& Card, D. (1985). Using the Longitudinal Structure of Earnings to Estimate the Effect of Training Programs. The Review of Economics and Statistics, 67(4), 648-660. https://doi:10.2307/1924810

Bai, Y., Chang, E. C., \& Wang, J. (2006). Asset prices and short-sale constraints. Social Science Electronic Publishing. https://dx.doi.org/10.5353/th_b3693434

Bernardo, A. E., \& Welch, I. (2004). Liquidity and financial market runs. Quarterly Journal of Economics, 119(1), 135-158. https://doi.org/10.1162/003355304772839542

Bris, A., Goetzmann, W., \& Zhu, N. (2007). Efficiency and the Bear: Short Sales and Markets around the World. The Journal of Finance, 62(3), 1029-1079. https://doi.org/10.1111/j.1540-6261.2007.01230.x

Chang, E. C. (2007). Short-sales constraints and price discovery: evidence from the hong kong market. Journal of Finance, 62(5), 2097-2121. https://doi.org/10.1111/j.1540-6261.2007.01270.x

Charoenrook, A., \& Daouk, H. (2004). The world price of short selling. Social Science Electronic Publishing.

Daouk, H., \& Charoenrook, A. A. (2009). A study of market-wide short-selling restrictions. Working Papers (51180).

Diamond, D. W., \& Verrecchia, R. E. (1987). Constraints on short-selling and asset price adjustment to private information. Journal of Financial $277-311$. https://doi.org/10.1016/0304-405X(87)90042-0

Fama, E. (1965). The Behavior of Stock-Market Prices. The Journal of Business, 38(1), 34-105. Retrieved from http://www.jstor.org/stable/2350752

Felipe, M. A., \& Javier, E. (2001). Empirical distributions of stock returns: european securities markets, 1990-95. European Journal of Finance, 7(1), 1-21. https://doi.org/10.1080/13518470121786

Gray, J. B., \& Dan, W. F. (1990). Empirical comparisons of distributional models for stock index returns. Journal of Business Finance \& Accounting, 17(3), 451-459. https://doi.org/10.1111/j.1468-5957.1990.tb01197.x

Jones, Charles M., \& Lamont, Owen A. (2002). Short-sale constraints and stock returns. Journal of Financial Economics, 66(2-3), 207-239.

Keim, D. B., \& Madhavan, A. (1995). Anatomy of the trading process empirical evidence on the behavior of institutional traders. Social Science Electronic Publishing, 37(3), 371-398.

Kon, S. J. (1984). Models of stock returns-a comparison. Journal of Finance, 39, 147-165. https://doi.org/10.2307/2327673

Miller, E. M. (1977). Risk, uncertainty, and divergence of opinion. Journal of Finance, 32(4), 1151-1168.

Morck, R. K., Yeung, B., \& Wu, W. (1999). The Information Content of Stock Markets: Why do Emerging Markets have Synchronous Stock Price Movements?. (Vol.58, pp.215-260). William Davidson Institute at the University of Michigan. https://dx.doi.org/10.2139/ssrn.194530

Myers, S. C., \& Jin, L. (2004). R-squared around the world: new theory and new tests. Social Science Electronic Publishing, 79(2), 257-292. https://dx.doi.org/10.2139/ssrn.531263

Reed, A. V. (2002). Costly short-selling and stock price adjustment to earnings announce-ments.

Wooldridge, J. M. (2009). Introductory econometrics a modern approach for wooldridge jeffrey in 1960. 


\section{Copyrights}

Copyright for this article is retained by the author(s), with first publication rights granted to the journal.

This is an open-access article distributed under the terms and conditions of the Creative Commons Attribution license (http://creativecommons.org/licenses/by/4.0/). 